\title{
Luminescence effects in Ag-doped cadmium bromide layered nanostructures
}

\author{
N.V.Stetsyk, V.G.Antonyuk, M.M.Rudka* \\ Department of Physical and Biomedical Electronics, I.Franko National \\ University of Lviv, 50 Dragomaova St., 79005 Lviv, Ukraine \\ *Department of Physics, Lviv Polytechnic National University, \\ 12 S.Bandera St., 79013 Lviv, Ukraine
}

Received May 23, 2014

\begin{abstract}
Temperature behaviors of X-ray luminescence, photoluminescence, and thermoluminescence were studied in cadmium bromide crystals doped with impurities of argentum from room temperature to liquid nitrogen temperature. It was found that the cadmium bromide crystals doped with impurities of argentum are sensitive to action of X-rays and ultraviolet light owing to the flow of photochemical reactions in these crystals.
\end{abstract}

Исследовано температурное поведение рентгенолюминесценции, фотолюминесценции и термолюминесценции монокристаллов $\mathrm{CdBr}_{2}: \mathrm{Ag}^{+}$от комнатной температуры до температуры жидкого азота. Обнаружено, что кристаллы $\mathrm{CdBr}_{2}: \mathrm{Ag}^{+}$чувствительны к действию рентгеновских лучей и ультрафиолетового света из-за протекания фотохимических реакций в этих кристаллах.

\begin{abstract}
Люмінесцентні властивості шаруватих наноструктур на основі бромистого кадмію, легованих домішками срібла. Н.В.Стецик, В.Г.Антонюк, М.М.Рудка.

Досліджено температурну поведінку рентгенолюмінесценції, фотолюмінесценції і термолюмінесценції монокристалів $\mathrm{CdBr}_{2}: \mathrm{Ag}^{+}$від кімнатної температури до температури рідкого азоту. Виявлено, що кристали $\mathrm{CdBr}_{2}: \mathrm{Ag}^{+}$чутливі до дії рентгенівських променів і ультрафіолетового світла через протікання фотохімічних реакцій в цих кристалах.
\end{abstract}

\section{Introduction}

Optical properties of $\mathrm{CdBr}_{2}$ crystals have been studied in previous works as well as applied research. Cadmium bromide is a layered crystal having fundamental energy gap of $5.4 \mathrm{eV}$ [1] and therefore it is widely used as optical material. Representing the wide group of divalent metal halides $\mathrm{CdBr}_{2}$ was thoroughly studied by optical spectroscopy techniques $[2,3]$. Particular attention was paid to explain the photochromism effect in pure and doped $\mathrm{CdBr}_{2}$ [4]. Much interest has recently been given to the search of the new materials, which can be used for efficient laminators.
Computed radiography (CR) using photostimulable phosphor storage media allows the combination of highly advanced photographic technology with digital computer techniques. This digital X-ray imaging technique is one of the primary candidates to replace the long-established screen-film radiography. Photostimulated luminescence (PSL) is a process where exposure to highenergy (X-ray or UV) photons results in accumulation of stored charges such as $\left[\mathrm{Cu}^{+} \mathrm{Cd}-\mathrm{Cu}^{+}{ }_{i}\right]$ centers. These stored charges can then be photostimulated to the conduction band using, for example, low-energy visible or near-infrared photons where they may recombine with holes to produce the visible photostimulated luminescence. X-ray 
storage crystals such as $\mathrm{CdBr}_{2}: \mathrm{Cu}^{+}$have been widely discussed in [3,7-10].

Unlike $\mathrm{CdBr}_{2}: \mathrm{Cu}^{+}$crystals, silver doped cadmium bromide has not been studied that much so far. Although $\mathrm{Ag}^{+}$ions (electronic configuration $4 d^{10}$ ) are homologically identical to $\mathrm{Cu}^{+}$, some differences in the absorption properties and in the photochromism nature for this material may be expected which have not been investigated in details [5].

The present authors have reported briefly on new results of the storage luminescence of $\mathrm{CdBr}_{2}: \mathrm{Ag}^{+}$crystals. In this paper, we present detailed observations and discussion on the temperature behaviors of $\mathrm{X}$-ray luminescence (XL), photoluminescence (PL), and thermoluminescence (TL) of $\mathrm{CdBr}_{2}: \mathrm{Ag}^{+}$single crystals from room temperature (RT) to liquid nitrogen temperature (LNT).

\section{Experimental}

Investigated samples were undoped as well as Ag-doped $\mathrm{CdBr}_{2}$ crystals. These nanocrystals were grown using the standard Bridgman-Stockbarger technique in sealed quartz ampoules $\left(\mathrm{CdBr}_{2}: \mathrm{Ag}^{+}-0.7 \%\right.$ by mass). Their crystalline structures were monitored using an X-ray diffractometer. The samples for measurements were then cut along the cleavage planes. Linear dimensions of the prepared rectangular specimens were nearly $5 \times 5 \mathrm{~mm}^{2}$. Several samples of different thickness were cut in order to select the best absorption layer thickness, thus ensuring the good quality of the absorption measurements. The investigations were performed at liquid nitrogen temperature because at this temperature the effect should be enhanced.

$\mathrm{X}$-ray irradiations were performed between 80 and $300 \mathrm{~K}$ with a W tube $(40 \mathrm{kV}$, $15 \mathrm{~mA})$. For UV illuminations, $150 \mathrm{~W} \mathrm{Xe}$ high-pressure lamp and $0.25 \mathrm{~m}$ grating monochromator were used. The heating rate above RT was $5{ }^{\circ} \mathrm{C} / \mathrm{s}$. Emission and excitation spectra were obtained by the luminescence spectrometer (Fig. 1).

To reduce impact of soft radiation that accompanies characteristic X-rays, an aluminum filter thickness of $0.5 \mathrm{~mm}$ was used. Additional measures for monochromaticity of X-ray was not performed. Scanning range was carried out using by the appropriate software.

To investigate the thermal curves, the samples were placed in a nitrogen cryostat and exposed to X-rays. Luminosity of the crystal was recorded during its heat with a

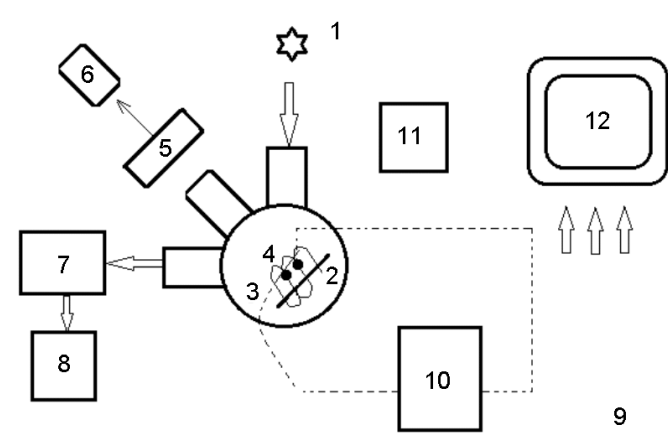

Fig. 1. Scheme of the experimental techniques for luminescence spectra study of: $1-$ source of X-ray; 2 - stem of cryostat; $3-$ sample; 4 - furnace; 5 - filters (to assess the thermal spectral composition); $6,8-$ photomultiplier tube PMT-79; 7 - monochromator MDR-12; 9 - ends of thermocouple HONEYWELL-700-U-0; 10 - control unit for linear heat rate; 11 - temperature controller "Utrex K 43"; 12 - computer.

linear speed of $0.1 \mathrm{~K}$ in single-photon mode using photoelectronic multiplier PMT-79 and recorded simultaneously with the temperature signal in the computer database. For temperature scanning the system of equipment was used, which included a control unit of linear velocity of the sample heating and temperature sensor of HONEYWELL-700-U-0 type.

Luminescence spectra were recorded by monochromator MDR-12 using photoelectronic multiplier PMT-79. Luminescence was excited by a helium-neon laser with line length of $337 \mathrm{~nm}$ and generating an output power of $40 \mathrm{~mW}$. Scanning and correction of the luminescence spectra were carried out automatically by computer processing of the signals recorded from the photoelectronic multiplier. The temperature of the sample placed in a nitrogen cryostat maintained to with an accuracy of $0.1 \mathrm{~K}$ through the system of temperature controller "Utrex K 43".

The roentgen luminescence ( $\mathrm{RL}$ or $\mathrm{X}$ Ray) spectra were recorded by monochromator MDR-12 with $0.5 \mathrm{~mm}$ holes of optical resolution of $2.5 \mathrm{~nm}$ using PMT-79. The samples were studied in a nitrogen cryostat of A-113 type with a beryllium window for $\mathrm{X}$-rays. Sign of luminescence was carried out through quartz window. Excitation of the samples was carried out using the apparatus URS-60 with molybdenum anode at a given voltage $55 \mathrm{kV}$, using $I=10 \mathrm{~mA}$. 


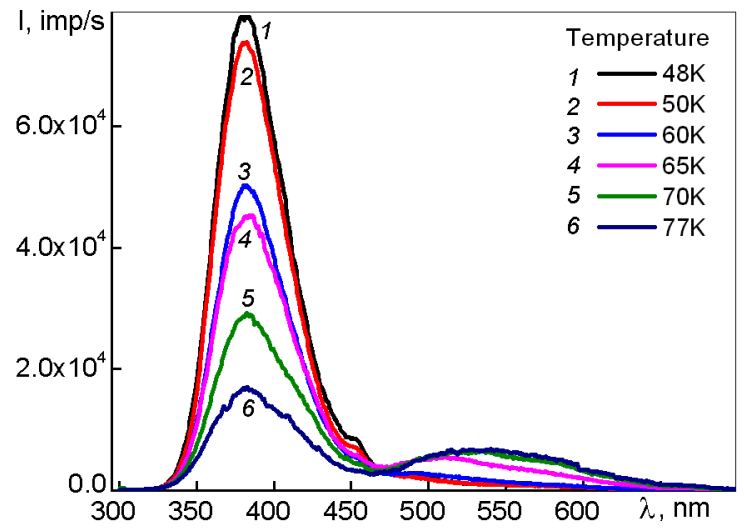

Fig. 2. Roentgen luminescence spectra of $\mathrm{CdBr}_{2}: \mathrm{Ag}^{+}$in the short-wavelength region. The main band was a narrow band at $365 \mathrm{~nm}$.

\section{Results and discussion}

3.1. X-Ray luminescence of cadmium bromide crystals doped with argentum impurities

The XL (X-ray luminescence) in shortwavelength region in temperature range of $48 \ldots 170 \mathrm{~K}$ is shown by the curves in Fig. 2 and Fig. 3. The emission consisted of the main narrow band at $365 \mathrm{~nm}$ as well as of some broad bands at about 500, 510, and $525 \mathrm{~nm}$. The bands at 500, 510 and $525 \mathrm{~nm}$ increase in intensity during cooling from $170 \mathrm{~K}$ to $100 \mathrm{~K}$; however, these three emission peaks are almost invisible at room temperature. Similarly, the emission at $365 \mathrm{~nm}$ is not seen at room temperature, but it appears at about $190 \mathrm{~K}$ and increases in intensity during further cooling and it becomes dominant at the liquid nitrogen temperature. These three emissions disappear at room temperature, indicating that they are not emissions from $\mathrm{Ag}^{+}$ions; they might be from some species created by $\mathrm{X}$-ray irradiation that is only stable at the low temperatures. Under X-ray irradiation, defects are created in the crystals. These defects may yield luminescence.

3.2. Photoluminescence of cadmium bromide crystals doped with argentum impurities

Activation of $\mathrm{CdBr}_{2}$ by impurities allows considerably to increase intensity, and to change the spectrum of their fluorescent glow. The impurities presence causes the increasing concentration both their own complexes, and generation of own-impurity or pure-impurity defects. It is shown in the absorption spectra, especially in the pho-

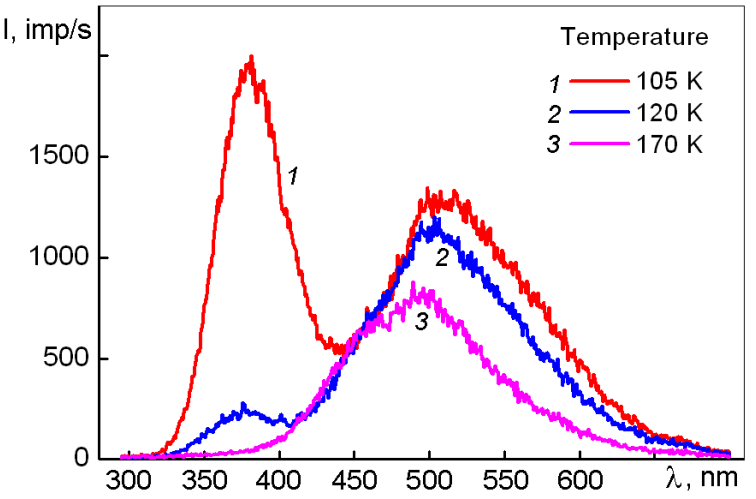

Fig. 3. Roentgen luminescence spectra of $\mathrm{CdBr}_{2}: \mathrm{Ag}^{+}$in the short-wavelength region. The main band was a narrow band at $365 \mathrm{~nm}$ as well as of some broad bands at about 500 , 510 , and $525 \mathrm{~nm}$.

toluminescence excitation spectra of the crystals [1, 2, 6]. Impurities of silver in cadmium bromide crystals are photochromic (Fig. 4). On the one hand, they are increasing the intensity of luminescence of cadmium bromide, and on the other hand they are sensitive to action of X-rays and ultraviolet light owing to the flow of photochemical reactions (FHR) in these crystals.

Fig. 4 shows that activation of crystals $\mathrm{CdBr}_{2}$ by silver is accompanied by the luminescence appearance with a maximum at $2.7 \mathrm{eV}$ region, which is internally-central character: the maximum position and its indicated luminescence intensity do not change in the investigated temperature range of $90 \ldots 300 \mathrm{~K}$. This luminescence is practically absent in the interband (including X-rays) excitation crystals $\mathrm{CdBr}_{2}: \mathrm{Ag}^{+}$, but manifested in the excitation light from the region of $3.68 \mathrm{eV}$. In this region of the spectrum selective absorption band of silver impurity centers is observed.

\subsection{Thermoluminescence in $\mathrm{CdBr}_{2}: \mathrm{Ag}^{+}$}

The direct-gap layered crystals of $\mathrm{CdBr}_{2}$ have strong ion-covalent bond within the structural layer $\mathrm{Br}-\mathrm{Cd}-\mathrm{Br}$ and weak van der Waals interaction between the layers. Significant defects layered crystals, including $\mathrm{CdBr}_{2}$, are accompanied by the presence of charge transfer tail on the long wavelength fundamental absorption edge and the advent of selective weakly intensive peaks on the SEL bulk samples at $4.54 \mathrm{eV}$. At excitation of the crystals by luminescence light of $4.54 \mathrm{eV}$ a wide range of superior maxima in the region $1.8 \mathrm{eV}$ is observed. Excitation $\mathrm{CdBr}_{2}: \mathrm{Ag}^{+}$at nitrogen temperature between 


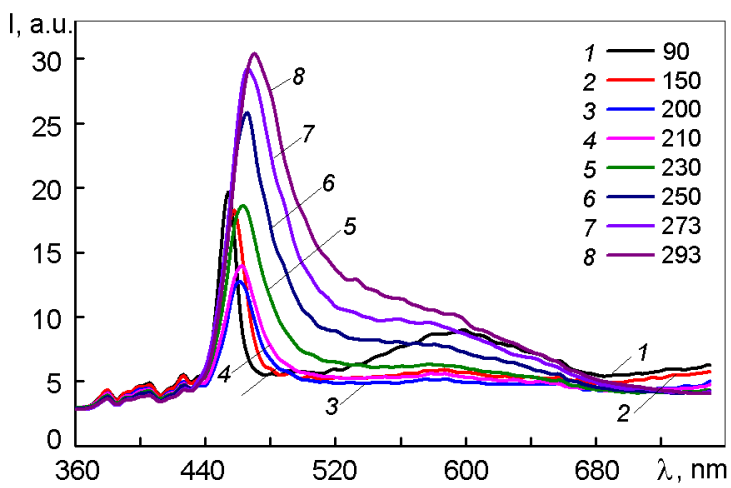

Fig. 4. Photoluminescence spectra of $\mathrm{CdBr}_{2}: \mathrm{Ag}^{+}$crystals.

the band of ultraviolet (UV) light or (X) rays of the curve thermoluminescence the slight maxima in the temperatures 50$60 \mathrm{~K}, 70-80 \mathrm{~K}$ and $90-170 \mathrm{~K}$ (Fig. 5) are present. Besides these there are intensive peaks of thermoluminescence (TSL) in the range of $200-300 \mathrm{~K}$.

Excitation crystals of "impurity" band $4.54 \mathrm{eV}$ in the curve (Fig. 5) is dominated by the low-temperature TSL peaks with maximum of green fluorescence at $2.48 \mathrm{eV}$ and mild highs under $236 \mathrm{~K}$ and $254 \mathrm{~K}$ with a predominant orange glow with a maximum at $1.8 \mathrm{eV}$.

\section{Conclusions}

In summary, X-ray luminescence, photoluminescence, and thermoluminescence were studied in $\mathrm{CdBr}_{2}: \mathrm{Ag}^{+}$single crystals from room temperature to liquid nitrogen temperature.

The X-ray luminescence spectrum in the short-wavelength region in the temperature range of $48 \ldots 170 \mathrm{~K}$ is consisted of a main narrow band at $365 \mathrm{~nm}$ as well as of some broad bands at about 500, 510, and $525 \mathrm{~nm}$. Luminescence is practically absent in the interband (including X-rays) excitation crystals $\mathrm{CdBr}_{2}: \mathrm{Ag}^{+}$, but manifested in the excitation light from the region of $3.68 \mathrm{eV}$. The crystals $\mathrm{CdBr}_{2}: \mathrm{Ag}^{+}$are sensitive to the action of $\mathrm{X}$-rays and ultraviolet light owing

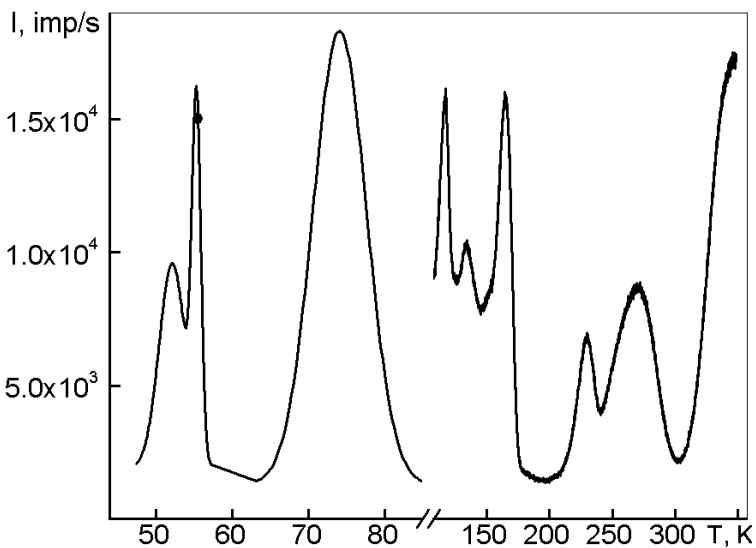

Fig. 5. Thermoluminescence spectrum of $\mathrm{CdBr}_{2}: \mathrm{Ag}^{+}$crystals.

to the flow of photochemical reactions in these crystals. As a result, the FHR cause the increasing of optical density in the samples and decreasing of the luminescence intensity.

\section{References}

1. A.B.Lyskovich, Wide-layered Crystals and their Physical Properties, High School, Lviv (1982) [in Russian].

2. M.Rudka, S.Charambura, V.Antonyuk et.al., Journal of Physical Studies, 4, 303 (2000).

3. N.Stetsyk, M.Rudka, V.Antonyuk, in: Proc. of the XIXth Intern. Seminar on Physics and Chemistry of Solids ISPCS-13, Czestochowa, Poland (2013), p.152,

4. N.Stetsyk, V.Antonyuk, M.Rudka, Electronics and Nanotechnology, in: Proc. of the XXXII Intern. Sci. Conf. ELNANO-2013 (2013), p.134.

5. S.S.Novosad, I.S.Novosad, A.V.Borodchuk, Inorg. Mater., 41, 187 (2005).

6. M.Catalano, A.Cingolani, R.Ferrara, M.Lepore, Helv. Phys. Acta, 58, 329 (1985).

7. R.Chen, P.L.Leung, Radiat. Meas., 33, 475 (2000).

8. R.D.Bringans, W.Y.Liang, J.Phys.C, 14(7), 1065 (1981).

9. K.Fukui, T.Kibara, H.Nakagava, UVSOR Act Rep., 140, 200 (2001).

10. H.Matsumoto, H.Nakagawa, H.Kuwabara, J. Phys.Soc.Jpn., 44, 957 (1978). 